\title{
Effect of Genotype and Genotype - Environment Interaction on Productive Performance of Japanese Quail Varieties
}

\author{
Khalid Hamid Hassan, Ali Rafea Abd-Alsattar \\ Department of Animal Production, College of Agriculture, University of Diyala, Baquba, Iraq
}

Email address:

Khaled@agriculture.uodiyala.edu.iq (K. H. Hassan), aaa2123aaa@gmail.com (A. R. Abd-Alsattar)

To cite this article:

Khalid Hamid Hassan, Ali Rafea Abd-Alsattar. Effect of Genotype and Genotype - Environment Interaction on Productive Performance of Japanese Quail Varieties. American Journal of BioScience. Vol. 4, No. 4, 2016, pp. 49-52. doi: 10.11648/j.ajbio.20160404.12

Received: July 25, 2016; Accepted: August 9, 2016; Published: August 25, 2016

\begin{abstract}
Two experiments were conducted at the poultry farm of Department of Animal Production - College of Agriculture - University of Diyala / Iraq, the first experiment performed in Autumn season using 324 birds and the second experiment performed in Spring season using 397 birds reared for ten weeks, the study aimed to detect the productive performance of three varieties of Japanese quail(White, Black and Brown plumage color) in the natural conditions of Iraq during Spring and Autumn seasons and the effect of genotype $\times$ environment interaction $(G \times E)$ on meat and egg production. The statistical analysis done according to factorial experiment in Completely Randomized Design $(3 \times 2)$ with three replicates. The results showed, significant superiority of the Black variety in the body weight measurements during the first 5 weeks of age, while there were no significant differences found in body weight between Black and Brown varieties during 6 and 7 weeks of age. There were significant differences due to $\mathrm{G} \times \mathrm{E}$ in body weight measurements of all weeks of rearing. The results showed significant superiority of the Black variety compared with White variety in feed consumption and weight gain traits, and also there were a significant superiority of measurements during Spring season rearing compared with Autumn season rearing in respect of weight gain and feed conversion traits, also there were significant $\mathrm{G} \times \mathrm{E}$ effect in feed conversion. There was a significant superiority of measurements during Autumn season rears in the age of sexual maturity of females, hen day egg production (\%), and the number of eggs per hen.
\end{abstract}

Keywords: Japanese Quail, Variety, Season Effect, G×E Interaction

\section{Introduction}

In the last decades, the Japanese quail (Coturnix coturnix) became within the commercial poultry industry for producing good quality flavored meat for human consumers with the inexpensive price compared with most poultry species. The rearing of quail can be practiced by many families because of the simple requirements and rearing area of the flock [1], in another hand, the rearing of quail represents attractive economic activity because of its rapid growth, early age of sexual maturity and high reproduction rate.

In spite of the lack of understanding about the living conditions and limitations that face family procedures [2], the family poultry production is an important activity in Asia, Africa, and Latin America [3].

The wild-type plumage color of the quail is predominantly dark cinnamon Brown, and male and female have some differences in plumage color, hence adult males have uniform dark rust-red feathers on the breast and Cheek, while adult females have pale breast feathers that are speckled with dark colored spots and these differences can be recognized at three weeks of age [4]. The difference between bird groups in plumage color can classify these groups to varieties [5].

Minvielle et al. [6] studied the effect of Roux plumage color on growth, carcass traits and egg production compared with wild-type plumage, the results referred that Roux color associated with significantly lower in the body weight, less abdominal fat and lower in egg weight. Islam et al. [7] found that there was significant superiority of White plumage in live body weight compared with Black variety.

Environmental conditions are playing important role in gene expression and as a result affect in quantitative traits. Conner and Hartl [8] referred to phenotypic plasticity, which means that the same genotype may produce different phenotypes in different environments and there are two types of genotype- environment interaction, the first has reaction norms cross and referred to as crossing $\mathrm{G} \times \mathrm{E}$, and the second type often called variance $\mathrm{G} \times \mathrm{E}$ because there are different genetic variance between environments. Breeder flocks that exposure to environmental challenges may introduce changes in behavior, physiology, and gene expression under both 
chronic and temporal conditions, and may be heritable changes in the parent and transmitted to their offspring [9].

Ozbey and Ozcelik [10] recorded a significant decline in live body weight, feed consumption and feed efficiency of Japanese quails in high environmental temperature $\left(35^{\circ} \mathrm{C}\right)$ compared with control group reared in $18-24^{\circ} \mathrm{C}$.

Iraq is located in the southwest of the continent of Asia extended from 29-37 North latitudes and longitudes 38-48 East, there are wide variations among the four seasons in Iraq with respect to temperature, moisture and day length. The monthly average temperatures in Iraq range from higher than $48^{\circ} \mathrm{C}$ (120 Fahrenheit) in July and August to below zero in January. The maximum environment temperature in Autumn ranged $17-30^{\circ} \mathrm{C}$ and in Spring $32-41^{\circ} \mathrm{C}$, while the minimum temperature ranged $14-28^{\circ} \mathrm{C}$ and $21-30^{\circ} \mathrm{C}$ for Autumn and Spring seasons respectively, and these variations affect the performance and viability of birds reared in the natural environment.

Hassan [11] studied the effect of rearing Brown variety quail in the natural environment during summer in Iraq on meat and egg production performance, using quails flock adapted to Iraqi conditions and the results recorded live body weight $158.07 \mathrm{~g}$ at 6 weeks of age and the uniformity among birds was $41.94 \%$, while the mean age of sexual maturity was 40.63 days. Hassan et al. [12] studied the effect of some non-genetic factors (including age and sex) and its effect on production traits, his results showed highly significant effect of bird age on the body weight, carcass weight, and significant effect of age on thigh weight, and a significant effect of sex on body weight, dress percentage, intestine length, liver weight percentage.

Hassan et al. [13] compared two varieties of Japanese quail (White plumage quail and Gray plumage quail) for their production performance and their results recorded highly significant differences between males and females in body weight, dress percentage, gizzard weight, liver weight and intestine length, and the significant effect of age $\times$ variety interaction on gizzard weight, beside the significant effect of age $\times$ sex interaction on liver weight. This experiment aimed to determine the effect of plumage color genotypes of quails on productive performance which recorded in the natural condition of Autumn and Spring seasons of Iraq, also determine the genotype-environment interaction effects on productive traits.

\section{Materials and Methods}

The experiments of the study conducted at the poultry farm of Dept. of Animal production -College of AgricultureUniversity of Diyala / Iraq, the first experiment performed in Autumn season using 324 birds and the second experiment performed in Spring season using 397 birds reared for ten weeks of age, the study aimed to detect the performance of three varieties of Japanese quail(White, Black and Brown plumage color) in the natural condition of Spring and Autumn seasons in Iraq and determine the effect of genotype $\times$ environment interaction $(\mathrm{G} \times \mathrm{E})$ on meat and egg production.

The statistical analysis of the data performed according to factorial experiment $3 \times 2$ in a Completely Randomized Design (CRD) and each treatment combination has three replicates, the significance of differences between means was determined by Duncan multiple range test [14] at 0.05 significant level.

\section{Results and Discussion}

The results recorded highly significant superiority $(\mathrm{P}<0.01)$ of Black plumage variety compared with other varieties in body weight during the period from one week to five weeks, while there was no significant difference between Black and Brown varieties in body weight at one day age, 6 and 7 weeks of age (Table 1), this result disagree with Islam et al [7].

The results showed highly significant differences in body weight between measurements of Autumn and measurements of Spring seasons. Hence, there was superiority in the body weight trait during Autumn season at one day age and the weeks 1, 2, 3, 4 of age, while there were superiority in body weight during Spring season at weeks 5, 6 and 7 of age. The multiple comparisons among group means revealed significant differences due to genotype $\times$ environment interaction in body weight of all periods of the study (Table 1).

Table 1. Means of body weight at different ages for a main effect and interaction between genotypes and environment in Japanese quail varieties.

\begin{tabular}{|c|c|c|c|c|c|c|c|c|}
\hline \multirow{2}{*}{ Traits } & \multicolumn{8}{|c|}{ Weight (g) at various ages (wk) } \\
\hline & One day & $1 \mathrm{wk}$ & $2 \mathrm{wk}$ & $3 \mathrm{wk}$ & $4 \mathrm{wk}$ & $5 \mathrm{wk}$ & $6 \mathrm{wk}$ & $7 \mathrm{wk}$ \\
\hline \multicolumn{9}{|c|}{ Genotypes (G) } \\
\hline White (W) & $7.50 \mathrm{~b}$ & $20.79 b$ & $42.58 b$ & $81.72 b$ & $116.56 \mathrm{~b}$ & $152.71 \mathrm{c}$ & $175.03 \mathrm{~b}$ & $184.27 \mathrm{~b}$ \\
\hline Black (B) & $7.74 \mathrm{a}$ & $24.24 \mathrm{a}$ & $50.17 \mathrm{a}$ & $90.29 \mathrm{a}$ & $125.85 \mathrm{a}$ & $161.51 \mathrm{a}$ & $187.62 \mathrm{a}$ & $197.58 \mathrm{a}$ \\
\hline Brown $(\mathrm{N})$ & 7.69ab & $21.17 b$ & $44.64 b$ & $82.15 b$ & $120.02 b$ & $156.47 \mathrm{~b}$ & $182.91 \mathrm{a}$ & $193.83 \mathrm{a}$ \\
\hline \multicolumn{9}{|l|}{ Seasons (E) } \\
\hline Autumn (A) & $7.81 \mathrm{a}$ & $24.10 \mathrm{a}$ & $51.47 \mathrm{a}$ & $89.48 \mathrm{a}$ & $123.83 a$ & $154.13 b$ & $175.74 \mathrm{~b}$ & $180.60 \mathrm{~b}$ \\
\hline Spring (S) & $7.48 b$ & $20.03 b$ & $40.12 b$ & $79.96 \mathrm{~b}$ & $117.79 b$ & $159.67 \mathrm{a}$ & $187.97 \mathrm{a}$ & $203.19 a$ \\
\hline \multicolumn{9}{|l|}{$\mathbf{G} \times \mathbf{E}$} \\
\hline WA & 7.74ab & $21.39 \mathrm{bc}$ & $45.76 \mathrm{bc}$ & $85.10 \mathrm{~b}$ & $120.10 \mathrm{bc}$ & $151.66 \mathrm{~d}$ & $171.65 \mathrm{~b}$ & $180.83 b$ \\
\hline WS & $7.26 \mathrm{c}$ & $20.19 \mathrm{~cd}$ & $39.40 \mathrm{~cd}$ & $78.34 \mathrm{c}$ & $113.01 \mathrm{~d}$ & $153.76 \mathrm{~cd}$ & $178.41 \mathrm{~b}$ & $187.71 \mathrm{~b}$ \\
\hline BA & $7.93 a$ & $28.97 \mathrm{a}$ & $60.29 a$ & $98.27 \mathrm{a}$ & $128.31 \mathrm{a}$ & $157.26 \mathrm{bc}$ & $179.69 \mathrm{~b}$ & $180.52 b$ \\
\hline BS & $7.56 \mathrm{~b}$ & $19.50 \mathrm{~d}$ & $40.04 d$ & $82.31 \mathrm{bc}$ & $123.40 \mathrm{ab}$ & $165.76 \mathrm{a}$ & $195.56 \mathrm{a}$ & $214.64 \mathrm{a}$ \\
\hline NA & $7.76 \mathrm{ab}$ & $21.94 \mathrm{~b}$ & $48.35 b$ & $85.10 \mathrm{~b}$ & $123.08 \mathrm{ab}$ & $153.46 \mathrm{~cd}$ & $175.88 \mathrm{~b}$ & $180.44 b$ \\
\hline NS & $7.62 \mathrm{~b}$ & $20.40 \mathrm{~cd}$ & $40.92 \mathrm{~cd}$ & $79.23 \mathrm{c}$ & $116.95 \mathrm{~cd}$ & $156.48 \mathrm{~b}$ & $189.94 \mathrm{a}$ & $207.22 \mathrm{a}$ \\
\hline
\end{tabular}

*Means have different superscript refer to a significant difference at $(\mathrm{P}<0.05)$ within each effect. 
The $\mathrm{G} \times \mathrm{E}$ interaction can appear in genetics studies in two forms, the first represents a change in variance between the performance of two genotypes as a result of a change of environment and the second type of interaction represents a cross-interaction included a change in the arrangement order of the performance of genotypes [8], hence, the results recorded no significant difference between measurements of White and Black varieties during Autumn season, while the results showed significant differences between measurements of these varieties during Spring season, which refer that Spring environment increased the variance between the measurements of these varieties (Table 1), also there was reverse situation in the second week of age, hence the results recorded a significant difference between White and Black varieties during Autumn season and appeared no significant differences between them during Spring season (Table 1). According to the results in Table 2, there were significant differences among all varieties in feed consumption while there were no significant differences in weight gain and mortality percentage between Black and Brown varieties. The results recorded lower feed conversion of Black variety compared with White and Brown varieties.

Table 2. Means of feed consumption, weight gain, feed conversion and mortality percentage of main effects and genotype $\times$ environment in Japanese quail varieties.

\begin{tabular}{lllll}
\hline Traits & Feed consumption (g/ 6 weeks) & Weight gain (g/ 6 weeks) & Feed conversion (g feed / g gain) & Mortality (\%) \\
\hline Genotypes (G) & & & & \\
White (W) & $566.58 \mathrm{c}$ & $167.53 \mathrm{~b}$ & $3.38 \mathrm{a}$ & $0.00 \mathrm{a}$ \\
Black (B) & $660.29 \mathrm{a}$ & $179.88 \mathrm{a}$ & $3.68 \mathrm{~b}$ & $2.58 \mathrm{ab}$ \\
Brown (N) & $609.58 \mathrm{~b}$ & $175.22 \mathrm{a}$ & $3.49 \mathrm{a}$ & $5.72 \mathrm{~b}$ \\
Seasons (E) & & & & \\
Autumn (A) & $614.93 \mathrm{a}$ & $167.93 \mathrm{~b}$ & $3.66 \mathrm{a}$ & $4.01 \mathrm{a}$ \\
Spring (S) & $609.37 \mathrm{a}$ & $180.49 \mathrm{a}$ & $3.37 \mathrm{~b}$ & $1.52 \mathrm{a}$ \\
G $\times$ E & & & & $0.00 \mathrm{a}$ \\
WA & $547.08 \mathrm{~d}$ & $163.91 \mathrm{~b}$ & $0.00 \mathrm{a}$ \\
WS & $586.08 \mathrm{c}$ & $171.15 \mathrm{~b}$ & $3.34 \mathrm{a}$ & $2.87 \mathrm{a}$ \\
BA & $680.55 \mathrm{a}$ & $171.76 \mathrm{~b}$ & $3.42 \mathrm{a}$ & $2.30 \mathrm{a}$ \\
BS & $640.04 \mathrm{~b}$ & $188.00 \mathrm{a}$ & $3.96 \mathrm{c}$ & $9.17 \mathrm{~b}$ \\
NA & $617.16 \mathrm{bc}$ & $168.11 \mathrm{~b}$ & $3.40 \mathrm{a}$ & $2.27 \mathrm{a}$ \\
NS & $602.00 \mathrm{c}$ & $182.32 \mathrm{a}$ & $3.68 \mathrm{~b}$ & $3.30 \mathrm{c}$ \\
\hline
\end{tabular}

*Means have different superscript refer to a significant difference at $(\mathrm{P}<0.05)$ within each effect.

The statistical analysis revealed no significant difference between the measurements of Autumn and Spring seasons in feed consumption and mortality percentage, while there were significant differences between measurements of Autumn and Spring seasons in weight gain (167.93 and $180.49 \mathrm{~g} /$ week) and feed conversion (3.66 and $3.37 \mathrm{~g}$ feed/ $\mathrm{g}$ weight gain). Also, the statistical analysis showed there were no significant effects of genotype $\times$ environment interaction on weight gain and mortality percentage, while there were significant differences in the $\mathrm{G} \times \mathrm{E}$ interaction mean of the feed consumption, hence, there were significant differences between White and Brown varieties in feed consumption during Autumn season and became no significant differences during Spring season.

Also, the results appeared significant differences between the $\mathrm{G} \times \mathrm{E}$ interaction means in feed conversion, hence, there were significant differences between White and Black varieties in Autumn and the differences between these varieties became no significance in the Spring season (Table 2).

Table 3. Means of sexual maturity, hen-day egg production, the number of eggs per hen and egg weight of the main effect and genotype $\times$ environment interaction in Japanese quail varieties.

\begin{tabular}{lllll}
\hline Traits & Sexual maturity (Day) & Hen-day Egg (\%) & Egg / Hen (Egg) & Egg weight (g.) \\
\hline Genotypes (G) & & & & $9.93 \mathrm{a}$ \\
White (W) & $39.67 \mathrm{a}$ & $68.22 \mathrm{a}$ & $36.83 \mathrm{a}$ & $9.83 \mathrm{a}$ \\
Black (B) & $40.67 \mathrm{ab}$ & $77.09 \mathrm{a}$ & $42.00 \mathrm{a}$ & $9.85 \mathrm{a}$ \\
Brown (N) & $41.00 \mathrm{~b}$ & $74.82 \mathrm{a}$ & $40.50 \mathrm{a}$ & $9.60 \mathrm{~b}$ \\
Seasons (E) & & & $43.89 \mathrm{a}$ & $10.14 \mathrm{a}$ \\
Autumn (A) & $38.22 \mathrm{a}$ & $78.68 \mathrm{a}$ & $35.67 \mathrm{~b}$ & $9.76 \mathrm{bc}$ \\
Spring (S) & $42.67 \mathrm{~b}$ & $68.07 \mathrm{~b}$ & & $10.11 \mathrm{ab}$ \\
G $\times \mathbf{E}$ & & & $37.33 \mathrm{bc}$ & $9.47 \mathrm{c}$ \\
WA & $38.33 \mathrm{a}$ & $67.34 \mathrm{~b}$ & $36.33 \mathrm{bc}$ & $10.18 \mathrm{a}$ \\
WS & $41.00 \mathrm{~b}$ & $69.10 \mathrm{~b}$ & $50.67 \mathrm{a}$ & $9.56 \mathrm{c}$ \\
BA & $38.00 \mathrm{a}$ & $90.29 \mathrm{a}$ & $33.33 \mathrm{c}$ & $10.14 \mathrm{a}$ \\
BS & $43.33 \mathrm{c}$ & $63.88 \mathrm{~b}$ & $43.67 \mathrm{ab}$ & $37.33 \mathrm{bc}$ \\
NA & $38.33 \mathrm{a}$ & $78.42 \mathrm{ab}$ & $71.23 \mathrm{~b}$ & \\
NS & $43.67 \mathrm{c}$ & & \\
\hline
\end{tabular}

*Means have different superscript refer to a significant difference at $(\mathrm{P}<0.05)$ within each effect. 
The statistical analysis showed significant differences between measurements of White and Brown varieties in the age of sexual maturity (39.67 and 41.0 days) while there were no significant differences among measurements of varieties in other traits of egg production included hen day egg production, number of egg / hen and egg weight (Table 3) Statistical analysis appeared significant differences due to $\mathrm{G} \times \mathrm{E}$ interaction at the age of sexual maturity, hen day production and number of eggs per hen, the results recorded no significant differences between measurements of White and Black varieties during Autumn and the differences became significant during Spring season, while the differences still no significant between measurements of Black and Brown varieties during both Autumn and Spring seasons (Table 3).

In respect of hen day production, the results recorded significantly differences between measurements of White and Black varieties during Autumn season and the differences became no significant during Spring season.

\section{Conclusions}

The results appeared the suitable market body weight at six weeks of age during Spring season. There were a superiority of the Black and Brown varieties in body weight and weight gain during the first six weeks of rearing compared with White variety. In respect of hen day egg production, there were no significant differences between White and Black varieties during Spring season, while there were significant superiority of Black variety in egg production during Autumn season, and that refered to $\mathrm{G} \times \mathrm{E}$ interaction between these varieties and the environment of Autumn and Spring seasons.

\section{References}

[1] Santos, T. C., Murakami, A. E., Fanhani, J. C. and Oliveira, C. A. Production and reproduction of Egg and Meat type quails reared in different group sizes. Brazilian Journal of Poultry Science, 13 (1): 9-14. 2011.

[2] Alders, R. G. Challenges, and opportunities for small- scale family poultry production in developing countries. XXIV World's Poultry Congress 5 - 9 August - 2012. Salvador - Bahia - Brazil. 2012.
[3] Figueiredo, E. A. P. Entrepreneurial small-scale family poultry production in developing countries. Proceedings of the XXIV World's Poultry Congress, Salvador. 2012.

[4] Tavaniello, S. Effect of cross-breed of meat and egg line on productive performance and meat quality in Japanese quail (Coturnix japonica) from different generations. Ph. D. Thesis, University of Molise. 2014.

[5] Hassan, K. H. Poultry Breeding. 1st Edition, Diyala University Press. Iraq. 2011.

[6] Minvielle, F., Hirigoyen, E., Boulay, M. Associated Effects of the Roux Plumage Color Mutation on Growth, Carcass Traits, Egg Production, and Reproduction of Japanese Quail. Poultry Sci. 78: 1479-1484. 1999.

[7] Islam, M. S., Faruque, S., Khatun, H., Islam, M. N. Comparative Production Performances of Different Types of Quail (Coturnix coturnix japonica). The Agriculturists 12 (2): 151-155. 2014.

[8] Conner, J. K., Hartl, D. L. A Primer of Ecological Genetics. $1^{\text {st }}$ Ed. Sinauer Associates, Inc., Publishers, USA. 2014.

[9] Nätt, D. Heritable epigenetic responses to environmental challenges. LiU-Tryck, Linköping, Sweden. 2011.

[10] Ozbey, O., Ozcelik, M. The effect of high environmental temperature on growth performance of Japanese quails with different body weights. International Journal of Poultry Science, 3 (7): 468-470. 2004.

[11] Hassan, K. H. Evaluation of productive performance of Japanese quail in summer of Iraq. Diyala Agricultural Science Journal, 5 (2): 69-80. 2013.

[12] Hassan, K. H., Ahmad, A. A., Dawood, T. A., Fadil, N. K. Study of dress percentage and relative weights of carcass parts in various ages of Japanese quail in Iraq. Diyala Agricultural Science Journal, 5 (2): 92-103.2013

[13] Hassan Khalid Hamid, Ali Rafea Abd - Alsattar, Homam Abed Al Kareem Yassen, Haeder Their Abed, Dalal Abed Alrazak Abdul Wahab. Effect of Variety, Age, and Sex in Some Productive Traits In Japanese Quail in Iraq. American Journal of BioScience, Vol. 3, No. 2, 2015, pp. 55-58. doi: 10.11648/j.ajbio.20150302.15.

[14] Duncan, D. B. 1955. Multiple range and multiple F test. Biometrics, 11: 1-42. 